\title{
EVALUATING SOCIO-CULTURAL BARRIERS TO ANTENATAL CARE UTILIZATION AMONG REPRODUCTIVE AGE WOMEN IN WUSHISHI AND ZUNGERU COMMUNITIES IN NIGER STATE, NIGERIA: A LOGISTIC REGRESSION APPROACH
}

\author{
Phillips Edomwonyi Obasohan ${ }^{1}$, Dorcas Nike Obasohan ${ }^{2}$, Egbako Umar Ahmed ${ }^{3}$, \\ Muhammad Jibril Toroko ${ }^{4}$ \\ ${ }^{1}$ Department of Liberal Studies, College of Administration and Business Studies, Niger State \\ Polytechnic, Bida Campus, Bida Niger State, Nigeria. \\ ${ }^{2}$ Federal Medical Centre/Comprehensive Health Centre, Zungeru, Niger State, Nigeria. \\ ${ }^{3}$ Department of Mathematics and Statistics, College of Science and Technology, Niger State \\ ${ }^{4}$ Polytechnic, Zungeru Campus, Zungeru, Nigeria
}

\begin{abstract}
*Corresponding Author: Phillips Edomwonyi Obasohan
Corresponding Author Email: philiobas@yahoo.com

Article Received: 25-07-19 Accepted: 20-11-19

Published: 02-12-19

Licensing Details: Author retains the right of this article. The article is distributed under the terms of the

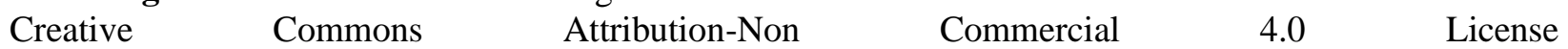
(http://www.creativecommons.org/licences/by-nc/4.0/) which permits non-commercial use, reproduction and distribution of the work without further permission provided the original work is attributed as specified on the Journal open access page
\end{abstract}

\begin{abstract}
More than $33 \%$ of Nigerian pregnant women do not use the Antenatal Care service during pregnancy. In 2015, for instance, World Health Organization (WHO) revealed that only $61 \%$ of Nigerian pregnant women had attended ANC at least once during their pregnancy period. Only $51 \%$ of these women met the WHO standard of a minimum of 4 visits. This ANC rate is, without doubt, lower than the WHO African region average of 77\%. The situation in Wushishi and Zungeru communities of Niger State may not be different. Despite the number of health facilities available in these communities, some women of childbearing age do not access antenatal care. Most times, many of them lose their lives during delivery at home, some end up with complications or lose
\end{abstract}


their babies at births. This situation raised concern why pregnant women do not attend antenatal care in health facilities around them? This paper examined the socio-cultural impediments to accessing antenatal care services among reproductive-aged women in Wushishi and Zungeru Communities of Niger State. We used a Multivariate Logistic Analysis. A total of 150 subjects were involved in this study comprising 83 from Zungeru and 67 from Wushishi. The questionnaire used for data collection was a structured consist of 17 items. The results indicated that ethnicity and preference for traditional birth attendant are major influences to accessing ANC in these communities

Keywords: Barriers, Ante Natal Care, Maternal Health Care, Social, Cultural Effect, Wushishi, Zungeru, Niger State, Impediments, logistic regression

\section{INTRODUCTION}

In Nigeria, more than $33 \%$ of pregnant women do not use the Antenatal Care service during pregnancy [1]. In 2015, world health statistics revealed that only $61 \%$ of Nigerian pregnant women had attended ANC at least once during their pregnancy period, and 51\% met the WHO standard of a minimum of 4 visits [2]. This ANC rate is, without doubt, lower than the WHO African region average of $77 \%[2,3]$.

Recent World Health Organization (WHO) statistics showed that ANC coverage between 2006 and 2013 correlates indirectly with the Maternal Mortality Ratio (MMR) worldwide [2]. This MMR indicates that countries with low ANC coverage are the ones with high MMR and vice versa. For instance, ANC coverage in the United Arab Emirates was 100\% with MMR of 8 per 100,000, and Ukraine had 99\% ANC coverage and MMR of 23 per 100,000. In most sub-Saharan Africa, access to ANC is low, thereby resulting in making maternal mortality disproportionately high compared with developed countries [4]. Ghana had ANC coverage of $96 \%$ and MMR of 380 per 100,000, Chad, on the other hand, had 43\% ANC coverage and an MMR of 980 per 100.000. Nigeria had ANC coverage of $61 \%$ and MMR of over 560. Nigeria's MMR is clearly above the African and global average of 500 and 210, respectively [1]. Given this, maternal mortality and morbidity have continued to pose challenges to health care delivery system [5]. The poor maternal health outcome in Nigeria could be a result of reduced ANC utilization.

In the recent times, a meta-synthesis was conducted to examine why women do not use ANC in Low and Medium Income countries. The results that cultural barriers such as superstitious belief concerning disclosure of pregnancy and shame associated with it because of its apparent relationship with sexual activities are significant factors [6]. Others have reported that in some places, husbands are often not willing to pay for cost attending health services [7]. Some reported unprofessional conduct brought about by conflict or poor communication among formal and informal health care providers with health service seekers, including failure to respect the privacy and confidentiality of the pregnant woman [8,9]. Also, a study carried out in Nepal discovered that women from disadvantaged ethnicity, lower women's autonomy, poor knowledge of maternal health service and incentive upon completion of ANC, were significantly associated with women who attended fewer than the WHO recommended 4 ANC visits. Thus, maternal health programs need to address such socio-cultural barriers for effective health care utilization [10]. 
The situations of ANC and MMR in Nigeria and elsewhere, as elaborated above, can also be assumed to be the situation in Wushishi and Zungeru Communities of Niger state. It is common to see pregnant women from these communities brought to the healthcare facilities bleeding while conducting business in the market place. Upon examination, they had suffered intrauterine fetal death for days in their womb. Despite the number of health facilities available in these communities, women of childbearing age are still not accessing antenatal care, and most times, many of them lose their lives during delivery at home, some end up with complications or lose their babies at births. This kind of situation raises concerns about why pregnant women do not attend antenatal care in health facilities around them? The authors are not aware of any paper to address these cultural barriers to utilization of ANC in Wushishi and Zungeru Communities of Niger State. So, this paper aims to examine if the prevalence of ANC utilization in these two communities differs and to determine the socio-cultural impediments to accessing antenatal care among women of childbearing age.

\section{Research Design}

Data used in this study and how it was collected been reported elsewhere [11]. A total of 150 subjects are involved in this study comprising 83 from Zungeru and 67 from Wushishi communities. These two communities have some public and private-owned health facilities that provide ANC services. The instrument used for data collection was a structured questionnaire that consist of 17 items. The questionnaire has two sections: A and B. Section A is on background data, and Section B are questions on ANC and barriers to utilization of antenatal care.

\section{Variable of Interest}

The Response (outcome or dependent) variable considered for this study is the number of times the respondent visited ANC during her last pregnancy, categorized as ' 0 ' if less than four times and ' 1 ' if more than three times. On the other hand the Predictor (Independent) variables include: Religion (Classified as '0' for Christians, ' 1 ' for Islam and ' 2 ' for Others); Marital Status (classified as ' 0 ' for Single, ' 1 ' for Married, '2' for Widow and ' 3 ' for Divorce); Ethnicity (classified as ' 0 ' for Nupe, ' 1 ' for Hausa/Fulani; '2' for Igbo, '3' for Yoruba and '4' for Others); Community Place of Residence (classified Zungeru as '0' and Wushishi as '1'); awareness of ANC; Receives husband support, Receives husband permission to attend ANC; likes workers attitude to patients; Believes in ANC; Prefers traditional birth attendant and fear of not meeting a female attendant (where each classified as ' 0 ' for Yes and ' 1 ' for No).

\section{Data Analysis}

To examine the relationship between selected women characteristics and ANC utilization in Wushishi and Zungeru Communities, we used the chi-square test at a 5\% level of significance. Using the classification of ANC visits, we computed the odds ratios and predictive probability of attending ANC for factors that were found significant at the bi-variable analysis stage. The computation was done using STATA version 14 for academic users [16]. 


\section{Ethical Approval}

The National Open University of Nigeria (NOUN) approved the Research Ethics for this study. Also, local administrative authorities in the two communities permitted to collect data, and the women who participated in the survey gave informed consent [11].

\section{RESULTS AND DISCUSSIONS}

Table 1: Relationship between Maternal Cultural Variables and Ante Natal Care Visits

\begin{tabular}{|c|c|c|c|}
\hline & No or partial visit & Fully visit & Chi-Square \\
\hline $\begin{array}{l}\text { Religion } \\
\text { Christians } \\
\text { Islam } \\
\text { Others } \\
\end{array}$ & $\begin{array}{c}7 \\
29 \\
0\end{array}$ & $\begin{array}{c}28 \\
82 \\
1 \\
\end{array}$ & 0,8666 (NS) \\
\hline $\begin{array}{l}\text { Marital Status } \\
\text { Single } \\
\text { Married } \\
\text { Widow } \\
\text { Divorce }\end{array}$ & $\begin{array}{c}1 \\
33 \\
2 \\
0\end{array}$ & $\begin{array}{c}2 \\
100 \\
4 \\
5\end{array}$ & 2.0097 (NS) \\
\hline $\begin{array}{l}\text { Ethnic Status } \\
\text { Nupe } \\
\text { Hausa } \\
\text { Igbo } \\
\text { Yoruba } \\
\text { Others } \\
\end{array}$ & $\begin{array}{c}9 \\
3 \\
2 \\
20 \\
2\end{array}$ & $\begin{array}{c}29 \\
14 \\
35 \\
23 \\
9\end{array}$ & $19.554(\mathrm{~S})$ \\
\hline $\begin{array}{l}\text { Communities } \\
\text { Zungeru } \\
\text { Wushishi }\end{array}$ & $\begin{array}{l}13 \\
23\end{array}$ & $\begin{array}{l}69 \\
42\end{array}$ & $7.48(\mathrm{~S})$ \\
\hline $\begin{array}{l}\text { Aware of ANC } \\
\text { No } \\
\text { Yes }\end{array}$ & $\begin{array}{l}13 \\
22\end{array}$ & $\begin{array}{c}7 \\
104\end{array}$ & $21.40(\mathrm{~S})$ \\
\hline $\begin{array}{l}\text { Husband Support } \\
\text { No } \\
\text { Yes }\end{array}$ & $\begin{array}{l}17 \\
18\end{array}$ & $\begin{array}{l}21 \\
90\end{array}$ & $12.152(\mathrm{~S})$ \\
\hline $\begin{array}{l}\text { Husband Permit } \\
\text { No } \\
\text { Yes }\end{array}$ & $\begin{array}{c}26 \\
9\end{array}$ & $\begin{array}{l}72 \\
36\end{array}$ & $0.563(\mathrm{NS})$ \\
\hline $\begin{array}{l}\text { Likes workers' attitudes } \\
\text { No } \\
\text { Yes }\end{array}$ & $\begin{array}{c}27 \\
8\end{array}$ & $\begin{array}{l}93 \\
18\end{array}$ & $0.801(\mathrm{NS})$ \\
\hline $\begin{array}{l}\text { Believes in ANC } \\
\text { No } \\
\text { Yes }\end{array}$ & $\begin{array}{l}24 \\
12 \\
\end{array}$ & $\begin{array}{l}87 \\
24 \\
\end{array}$ & $2.016(\mathrm{NS})$ \\
\hline $\begin{array}{l}\text { Prefer traditional birth attendants } \\
\text { No } \\
\text { Yes }\end{array}$ & $\begin{array}{c}27 \\
9\end{array}$ & $\begin{array}{c}106 \\
5\end{array}$ & $13.25(\mathrm{~S})$ \\
\hline $\begin{array}{l}\text { Fear of not meeting female worker } \\
\text { No } \\
\text { Yes }\end{array}$ & $\begin{array}{c}33 \\
3\end{array}$ & $\begin{array}{c}104 \\
7\end{array}$ & $0.176(\mathrm{NS})$ \\
\hline
\end{tabular}

NS=Not significant, $\mathrm{S}=$ Significant, $\mathrm{p}$-values $<0.05$ 
Table 1 displayed the results obtained from analyzing the relationship between the maternal sociocultural variables and ANC visits. It revealed that the prevalence of ANC utilization in Zungeru is $84.1 \%$, clearly above the WHO African region, and Nigeria averages of $77 \%$ and $61 \%$, as reported in $[2,3]$. On the other hand, the ANC prevalence for Wushishi was 64.6\%, and this is clearly below the WHO African region average, but slightly above the Nigerian Average [2,3]. It was observed that the ethnic status of the respondent (chi-sq=19.55, $\mathrm{p}=0.001$ ), the community where she lives in (chi-sq=7.48, p=0.006), her being aware of ANC (chi-sq=21.4, $\mathrm{p}=0.000$ ), not receiving supports from her husband (chi-sq=12.152, $\mathrm{p}=0.000$ ) and preference to access traditional birth attendant (chi-sq=13.25, $\mathrm{p}=0.000$ ), were factors significantly associated with antenatal care visits in Wushishi and Zungeru communities of Niger State Nigeria. These findings agree with those expressed in [7,10] Interestingly; the results showed that, against all expectations, religious affiliations, health worker attitude to their patients and fear of not going to meet a female staff on duty to attend to her, were not significantly associated with antenatal care visits

\section{Logistic Regression Analysis}

Table 2 showed the results obtained in further analysis of all the significant variables to determine the likelihood effects of the disparities existing in the variables associated with ANC utilization, using logistic regression analysis. We examined six models with each of the five significant variables (model 1-5) treated independently (as unadjusted odds ratio), and adjusted for all the significant variables considered for combined associations in the last model.

Table 2: Logistic Regression Analysis of Maternal Ante Natal Care Visits

\begin{tabular}{|c|c|c|c|c|c|c|}
\hline Variables & $\mathrm{OR}_{\mathrm{UA}}(1)$ & $\mathrm{OR}_{\mathrm{UA}}(2)$ & $\mathbf{O R}_{\mathrm{UA}}(3)$ & $\mathbf{O R}_{\mathrm{UA}}(4)$ & $\mathbf{O R}_{\mathrm{UA}}(\mathbf{5})$ & $\mathrm{OR}_{\mathrm{A}}(6)$ \\
\hline $\begin{array}{l}\text { Ethnic Status } \\
\text { Nupe } \\
\text { Hausa } \\
\text { Igbo } \\
\text { Yoruba } \\
\text { Others } \\
\end{array}$ & $\begin{array}{l}1.00 \\
1.44 \\
5.58^{*} \\
0.35^{*} \\
1.40 \\
\end{array}$ & & & & & $\begin{array}{l}1.00 \\
2.09 \\
4.94 \\
0.30 \\
0.66 \\
\end{array}$ \\
\hline $\begin{array}{l}\text { Communities } \\
\text { Zungeru } \\
\text { Wushishi }\end{array}$ & & $\begin{array}{l}1.00 \\
0.34 *\end{array}$ & & & & $\begin{array}{l}1.00 \\
0.56\end{array}$ \\
\hline $\begin{array}{l}\text { Aware of ANC } \\
\text { No } \\
\text { Yes }\end{array}$ & & & $\begin{array}{l}1.00 \\
8.77 *\end{array}$ & & & $\begin{array}{l}1.00 \\
4.38^{*}\end{array}$ \\
\hline $\begin{array}{l}\text { Receive a Husband. Support } \\
\text { No } \\
\text { Yes }\end{array}$ & & & & $\begin{array}{l}1.00 \\
4.047 * * \\
\end{array}$ & & $\begin{array}{l}1.00 \\
1.94 \\
\end{array}$ \\
\hline $\begin{array}{ll}\text { Prefer Traditional } & \text { Birth } \\
\text { Attendant } & \\
\text { No } \\
\text { Yes }\end{array}$ & & & & & $\begin{array}{l}1.00 \\
0.141 *\end{array}$ & $\begin{array}{l}1.00 \\
0.141 *\end{array}$ \\
\hline
\end{tabular}

$\mathrm{OR}_{\mathrm{UA}}=\mathrm{Un}$-Adjusted Odd Ratio; $\mathrm{OR}_{\mathrm{A}}=$ Adjusted Odd Ratio; ${ }^{*} \mathrm{p}<0.05$ 
Model 1 found that being a pregnant woman of Igbo ethnicity is significantly 5.58 times more likely to visit ANC during her pregnancy compare to a woman of Nupe origin (reference category). The reason for this discrepancy may not be unconnected with the fact that the Igbos who are from the Southeast Geopolitical Zone are often classified as non-indigenes residing in this part of the country and are more enterprising than any other tribes in these communities. Surprisingly, the result showed that a Yoruba woman is 0.65 less likely to visit ANC when compared with a Nupe woman. The reason for this is not entirely apparent, and this can be subject to further investigation. Model 2 revealed that staying in Wushishi makes a woman 66\% less likely to visit ANC than one that stays in Zungeru. This finding is not unexpected because Zungeru is more cosmopolitan than Wushishi. Zungeru is a community of diverse ethnic groups (fondly referred to as community of 'settlers'), while, Wushishi is occupied by more of the indigenous people from the community. Model 3 discovered that a woman who is aware of the importance of ANC is 8.7 times more likely to use ANC during her pregnancy than a woman who is not aware of it. This result further explained the relevance of the information to health care delivery processes. Model 4 explained that a woman who receives support from her husband is 4.05 more likely to access ANC compare with those who had no support. The reason for this may not be far from the fact that women in rural Nigeria are less enterprising and less autonomous. They depend so much on their husbands for almost everything, including decisions concerning their health-seeking behavior [17]. Model 5 on preference for traditional birth attendants showed that women who prefer to use TBA are 0.86 less likely to go for ANC than the one who does not use TBA. Furthermore, while adjusting for all the significant associated variables in model 6 , the result showed that only being aware of ANC and preference for traditional birth attendants remained significant. Likelihood for being aware of ANC dropped by half after adjusting, while, for TBA it remains unchanged (This result for TBA is striking as to why it is so.

\section{CONCLUSION}

This study which referred to two communities: Zungeru and Wushishi, is timely. Although they are neighbors to one another, they exhibit different socio-cultural backgrounds. The study is timely to address issues such as maternal health care service utilization as we match towards actualizing Sustainable Development Goals (SDGs) by 2030. The findings are undoubtedly salient and unexpected, as were the cases in some variables, and this will go a long way to assist policymakers in making informed decisions that will increase ANC utilization in these communities and Nigeria at large.

\section{Recommendations}

With respect to the findings in this research, we proffer the following recommendations:

1. There should always be constant community awareness campaign by healthcare provider primarily through community leaders for the need for Ante Natal Care services available in these communities

2. Community leaders in a less advantageous ethnic area like in Wushishi should be encouraged to speak regularly through women leaders of the importance of ANC to a pregnant woman 
3. Legislation can be in place to mandate the husband responsible for any pregnancy to be prepared to take financial responsibilities, especially the ones associated with ANC.

4. Access to ANC services in Nigeria should be made cost-free

5. To look out a way to integrate Traditional Birth Attendants into our maternal health care system by giving the training on model skills of delivery, especially safety devices on sterilization of instruments and prompt referral.

\section{References}

1. Fagbamigbe, A.F., \& Idemudia, E.S. (2015). Barriers to Antenatal care use in Nigeria: evidences from non-users and implications for maternal health programming. BMC (pregnancy and childbirth). 15, 95. DOI 10.1186/S 12884-015-0527-YS

2. World Health Organization, (2015). Making Pregnancy Safer Provision of Effective Antenatal Care: Integrated Management of Pregnancy and Childbirth. www.who.int/reproductivehealth

3. Fagbamigbe, A.F., \& Idemudia, E.S. (2013). Wealth and Antenatal Care Utilization in Nigeria: Policy Implications. Health Care Women International, 38(1), 17-37.

4. Ford-Richardson, L., Kin, S.C., Walker, M., Muckle, W, Sprague, A., Fergus, S., White, R.R., Dick, B. (2013). Barriers to Access of Maternity Care in Kenya: A Social Perspective. Journal of Obstetric Gynecology Canada. 35(2),125-130. doi: 10.1016/S17012163(15)31016-1

5. Pandey, S., Karki, S. (2014). Socio-economic and Demographic Determinants of Antenatal care Services Utilization in Central Nepal. International Journal of MCH and AIDS. 2(2), 212-219.

6. Finlayson, K., Downe S. (2013). Why do women not use Antenatal services in Low- and Middle-Income Countries? A meta-synthesis of Qualitative Studies. PLOS Medicine, 10 (1).

7. Wilunda, C., Scanagatta, C., Putoto, G., Montalbetti, F., Segafredo, G., Takahashi, R., Mizerero, S.A., \& Betrán, A.P. (2017). Barriers to Utilisation of Antenatal Care Services in South Sudan: A Qualitative Study in Rumbek North County, Reproductive Health, 14, 65. 10.1186/s12978-017-0327-0

8. Amnesty International. (2014). Struggle for Maternal Health: Barriers to Antenatal Care in South Africa. Amnesty International Secretariat, United Kingdom, 2014

9. Breckenrigde, J., Daraney, J., Kroll, T., Lazenbatt, A., Taylor, J., Bradbury-Jones, C. (2010). Access and Utilization of Maternity Services for Disabled Women who experience Domestic Abuse.

10. Deo, K.K., Paudel, Y,R., Khatri, R.B., Bhaskar, R.K., Paudel, R., Mehata, S., and Wagle, R.R. (2015). Barriers to Utilization of Antenatal Care Services in Eastern Nepal. Front Public Health, 3, 197. doi:10.3389/fpubh.2015.00197

11. Obasohan, D.N., Karo, H., Obasohan, P.E. (2017). Socioeconomic and Demographic Barriers in Assessing Ante Natal Care Services among Women of Child Bearing Age in 
Wushishi Local Government Area of Niger State, Nigeria, World Journal of Pharmaceutical Research, 7(1), 1264-1271.

12. Wikipedia contributors. (2019). Logistic regression. Wikipedia, The Free Encyclopedia,https://en.wikipedia.org/w/index.php?title=Logistic_regression\&oldid=884 272054

13. Garb, H.M.K. (2016). Investigating Poverty and Labour Force Participation among Older Population in Egypt: A Multilevel Simultaneous Equations Modelling Approach. Thesis Submitted to The University of Birmingham for the degree of PhD in Statistics, 2016

14. Schiippert, A. (2019). Binomial (or Binary) Logistic Regression. 9Statistic Seminar 2009 in http://www.let.rug.nl/nerbonne/teach/rema-stats-meth-semin

15. Medcalc Software. (2019). Logistic Regression available on https://www.medcalc.org/manual/logistic_regression.php

16. Stata Corporation. (2014). Stata Statistical Software. College Station, TX, 2014

17. National Population Commission and ICF Macro. (2013). Nigeria Demographic and Health Survey 2013. Abuja, Nigeria. 